\title{
Determination of (in)compatibility genotypes of Hungarian sweet cherry (Prunus avium L.) accessions by PCR based methods
}

\author{
Békefi, Zs. ${ }^{1}$, Tobutt, K. R. ${ }^{2}$ and Sonneveld, T. ${ }^{2}$ \\ ${ }^{I}$ Research Institute for Fruitgrowing and Ornamentals, H-1223 Budapest, Park u. 2., Hungary \\ ${ }^{2}$ Horticulture Research International, East Malling, West Malling, Kent ME19 6BJ, United Kingdom
}

\begin{abstract}
Summary: Sweet cherries (Prumus avium L.) are generally self-incompatible and pollinator cultivars are needed in orchards for reliable yield. In Hungary, choosing the appropriate cross-compatible cultivar pairs has so far been based on traditional test-crosses in the field. In recent years PCR-based methods that allow the identification of the $S$-alleles responsible for compatibility have been elaborated. We have determined the $S$-allele constitution of 24 cultivars and four selections important to Hungarian growers and breeders using PCR-based methods developed at Horticulture Research International, East Malling. The 28 accessions had various pairs of 9 alleles including one new allele, $S_{X}$. They could be assigned to 12 of the existing incompatibility groups or to a new group $\left(S_{4} S_{I 2}\right)$ for which the designation 'Group XXVII' is proposed. The cultivars 'Krupnoplodnaja' and 'Rita' had novel genotypes, $S_{5} S_{9}$ and $S_{5} S_{x}$, respectively and can be placed into group O that holds universal pollen donors. The genotype of the cultivar 'Hedelfingeni Orias' grown in Hungary was found to be $S_{3} S_{4}$ and therefore different from the cultivar 'Hedelfingen' that is widespread in Western Europe.
\end{abstract}

Key words: incompatibility, sweet cherry, $S$-alleles

\section{Introduction}

Self-incompatibility in sweet cherry and crossincompatibility between various cultivar pairs has been known for a long time (Gardener, 1914; Kobel \& Steinegger, 1933; Crane \& Brown, 1937). These phenomena were attributed to a multi-allelic locus, $S$, by Crane \& Lawrence (1929). The alternative forms of $S$-alleles are designated $S_{1}, S_{2}, S_{3}$, etc. Cultivars bearing the same combination of $S$-alleles can not fertilise each other and constitute an incompatibility group. The cultivars within the same incompatibility group are cross-incompatible but compatible with cultivars in all other groups and can fertilise each other if they bloom at the same time. Although sweet cherry is basically self-incompatible, Lewis \& Crowe (1954) using $\mathrm{X}$-irradiated pollen for nominally incompatible pollinations obtained some self-compatible selections. In the selection JI 2420 the $S_{4}$ allele had mutated to $S_{4}$ (Lewis \& Crowe, 1954; Matthews, 1970) and in JI 2434 the $S_{3}$ allele to $S_{3}^{\prime}$ (Bošković et al., 2000) where the prime symbol indicates a mutation in the pollen part.

Until recently sweet cherry compatibility was studied mostly with traditional test crossings. Thus in Hungary, Maliga (1952) tested the cross-compatibility of 'Badacsonyi Orias' and 'Germersdorfi Orias' (considered the same as 'Schneiders Späte Knorpelkirsche') with other Hungarian cultivars and determined two inter-incompatible cultivar pairs. Likewise Brózik (1962) carried out compatibility studies in 'Germersdorfi Orias' and determined suitable pollinators. Brózik \& Nyéki (1975) specified groups of Hungarian cultivars that are not only cross-compatible but bloom simultaneously. These authors later determined some incompatibility groups of Hungarian cultivars (Brózik \& Nyéki 1980). Nyéki (1989) classified various Hungarian and foreign cultivars into incompatibility groups, work completed by Nyéki \& Szabó (1995). Apostolné (1994) clarified compatibility relationships of several new Hungarian cultivars. Szabó et al. (2002) summarised the knowledge about Hungarian sweet cherry compatibility.

Matthews \& Dow (1969), drawing on test crossing results from the John Innes Institute and overseas, published the $S$ genotype of some 160 cultivars. This classic work became an important compilation for the scientists studying sweet cherry incompatibility. They reported six $S$-alleles and assigned cultivars into 13 incompatibility groups. Later, using stylar protein analysis, Bošković \& Tobutt (2001) reexamined the $S$-genotypes of the cultivars to be found in the work of Matthews \& Dow (1969): genotypes of some cultivars were corrected and some additional cultivars were assigned to incompatibility groups.

The work of Bošković \& Tobutt (1996) demonstrated that the products of sweet cherry $S$-alleles are stylar ribonucleases, the so called $S$-RNases. This finding led to molecular techniques of genotyping and so revolutionised 
cherry incompatibility studies. Analysing S-RNases extracted from the style resulted in the findings of new S-alleles and incompatibility groups (Bošković et al. 1997; Bošković \& Tobutt 2001).

Recently, PCR-based methods have been developed that enable $S$-genotypes of sweet cherry to be determined from vegetative material such as leaves and buds. Some authors (Tao et al., 1999; Wiersma et al, 2001) designed consensus primer pairs to amplify the two intron regions $\left(1^{\text {st }}\right.$ and $2^{\text {nd }}$ intron) and separate certain $S$-alleles on the basis of their intron length polymorphism. Sonneveld et al. (2003) has also developed consensus primers that are more generally useful. Sonneveld et al. (2001 and 2003) designed allele-specific primer pairs: each can detect one particular $S$-allele so they are ideal for confirming $S$-allele scores derived from consensus primer analysis.

Results of recent $S$-genotyping of sweet cherry cultivars have been summarised by Tobutt et al. (2001). Thirteen $S$-alleles $\left(S_{1}\right.$ to $S_{16}$, excluding $S_{8}, S_{11}$ and $S_{15}$, which are duplicates) and 26 incompatibility groups are known at the moment in sweet cherry, along with a group $\mathrm{O}$ of unique genotypes which are universal pollen donors and the SC group containing self-compatible cultivars (Tobutt et al., in press).

Our aim was to clear up compatibility relationships among various old and novel cultivars important in Hungary and new selections by means of $S$-allele analysis. In the interest of completeness, results of 'Alex', 'Aida' and 'Peter' are included, although they have recently been genotyped by Sonneveld et al. (2003).

\section{Material and method}

\section{Plant materials}

The accessions analysed were growing in the experimental field of the Research Institute for Fruitgrowing and Ornamentals in Erd (Table 1). Shoots bearing dormant buds have collected from the nuclear stock plantation (cultivars) and from research trial plots (selections). Cultivars used as standards came from the collection of Horticulture Research International, East Malling (Table 2). Genomic DNA was extracted from buds according to a miniprep version of the CTAB method (Doyle \& Doyle, 1987) as modified by Sonneveld et al. (2001).

Table I Cherry accessions analysed and their parentages where known

\begin{tabular}{|c|c|c|c|c|}
\hline Cultivars & Country of origin & Mother & Father & \\
\hline Alex & Hungary & Van & Cherry Self Fertile 46 (JI 2538?)* & Brózik, S., Apostol, J. (2000) \\
\hline Botond & Hungary & $?$ & $?$ & \\
\hline Germersdorfi I & Hungary & & & \\
\hline Germersdorfi 3 & Hungary & & & \\
\hline Hedelfingeni Orias & Hungary & 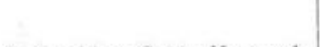 & & \\
\hline Katalin & Hungary & Schneiders Späte Knorpel & Podjebrad & Brózik S., Apostol J. (2000) \\
\hline Kavics & Hungary & Schneiders Späte Knorpel & Budakalászi helyi fekete & Brózik S., Apostol J. (2000) \\
\hline Krupnoplodnaja & Hungary & $?$ & $?$ & \\
\hline Linda & Hungary & Hedelfingeni Orias & Schneiders Späte Knorpel & Brózik S., Apostol J. (2000) \\
\hline Margit & Hungary & Schneiders Späte Knorpel & o.p. & Brózik S., Apostol J. (2000) \\
\hline Münchebergi Korai & Germany & Flamentiner(?) & Márki korai & Brózik S., Apostol J. (2000) \\
\hline Solymári Gömbölyũ & Hungary & & & \\
\hline Szomolyai Fekete & Hungary & & & \\
\hline Trusenszkaja 2 & Russia & & & \\
\hline Valerij Cskalov & Russia & & & Brózik S Anostol J (2000) \\
\hline Vera & Hungary & Ljana (Trusenszkaja 6) & Van & Brózık S., Apostol J. (2000) \\
\hline \multicolumn{5}{|c|}{ candidate cultivars (novelties) from Budapest, Research Institute for Fruitgrowing and Ornamentals } \\
\hline III-42/114 (Carmen) & & Yellow Dragan & H 203 & Brózik S., Apostol J. (2000) \\
\hline IV-3/4I (Anita) & & Trusenszkaja 2 & H 3 & Brózik S., Apostol J. (2000) \\
\hline IV-5/62 (Rita) & & Trusenszkaja 2 & $\mathrm{H} 2$ & Brózik S., Apostol J. (2000) \\
\hline IV-6/5 (Péter) & & Bigarreau Burlat & Stella & Brózik S., Apostol J. (2000) \\
\hline IV-6/12 (Sándor) & & Bigarreau Burlat & Stella & Brózik S., Apostol J. (2000) \\
\hline IV-6/39 (Pál) & & Bigarreau Burlat & Stella & Brózik S., Apostol J. (2000) \\
\hline IV-13/20 (Aida) & & Moldvai Fekete & H 236 & Brózik S., Apostol J. (2000) \\
\hline IV-13/51 (Tünde) & & Yellow Dragan & Bigarreau Burlat & Brózik S., Apostol J. (2000) \\
\hline \multicolumn{5}{|c|}{ hybrids, breeding lines from Budapest, Research Institute for Fruitgrowing and Ornamentals } \\
\hline IV $-5 / 5$ & & Trusenszkaja 2 & $\mathrm{H} 1$ & Apostol (pers. comm.) \\
\hline IV $-6 / 66$ & & Bigarreau Burlat & Stella & Apostol J, Brózik S (1998) \\
\hline IV $-6 / 240$ & & $?$ & $?$ & \\
\hline IV $-13 / 120$ & & Yellow Dragan & Bigarreau Burlat & Apostol (pers. comm.) \\
\hline
\end{tabular}




\section{PCR with consensus primers}

Preparation of a $25 \mu \mathrm{l}$ PCR amplification reaction, its content, final concentrations, the number of PCR cycles and temperatures were performed according to the protocol described by Sonneveld et al. (2003). The consensus primers used were: $2^{\text {nd }}$ intron, PaConsII-F and PaConsII-R; $1^{\text {st }}$ intron, PaConsI-F and PaConsI-R (Sonneveld et al., 2003). A negative control (water) was included. PCR reactions were carried out in a PTC-200 thermal cycler (MJ Research).

PCR products were separated by electrophoresis, for the $2^{\text {nd }}$ intron on a $1.3 \%$ agarose gel for $16 \mathrm{~h}$ at $60 \mathrm{~V}$ and for the $1^{\mathrm{st}}$ intron on a $2.0 \%$ agarose gel for $17 \mathrm{~h}$ at $60 \mathrm{~V}$. Molecular weight ladders, $1 \mathrm{~kb}+$, were included. After electrophoresis the gels were stained in a $0.5 \mu \mathrm{l} / \mathrm{ml}$ ethidium-bromide solution for $1 \mathrm{~h}$. Photographs were taken on an ultraviolet transilluminator. Provisional genotypes deduced by comparing banding patterns of the Hungarian cultivars with those of the standard cultivars.

\section{PCR with allele-specific primers}

After provisional genotypes had been deduced from the amplification patterns of the consensus primers separate PCR reactions were set up with different allele-specific primers (Sonneveld et al., 2001, 2003) and annealing temperatures according to the protocol described by Sonneveld et al. (2003) (Table 3). In order to avoid false negatives in PCR reactions an additional internal control primer pair was used in each reaction (Sonneveld et al., 2003). PCR products were run on a $1.5 \%$ agarose gel for $1 \mathrm{~h}$ at $90 \mathrm{~V}$. Then the gels were handled as described in the analysis of the $2^{\text {nd }}$ intron above.

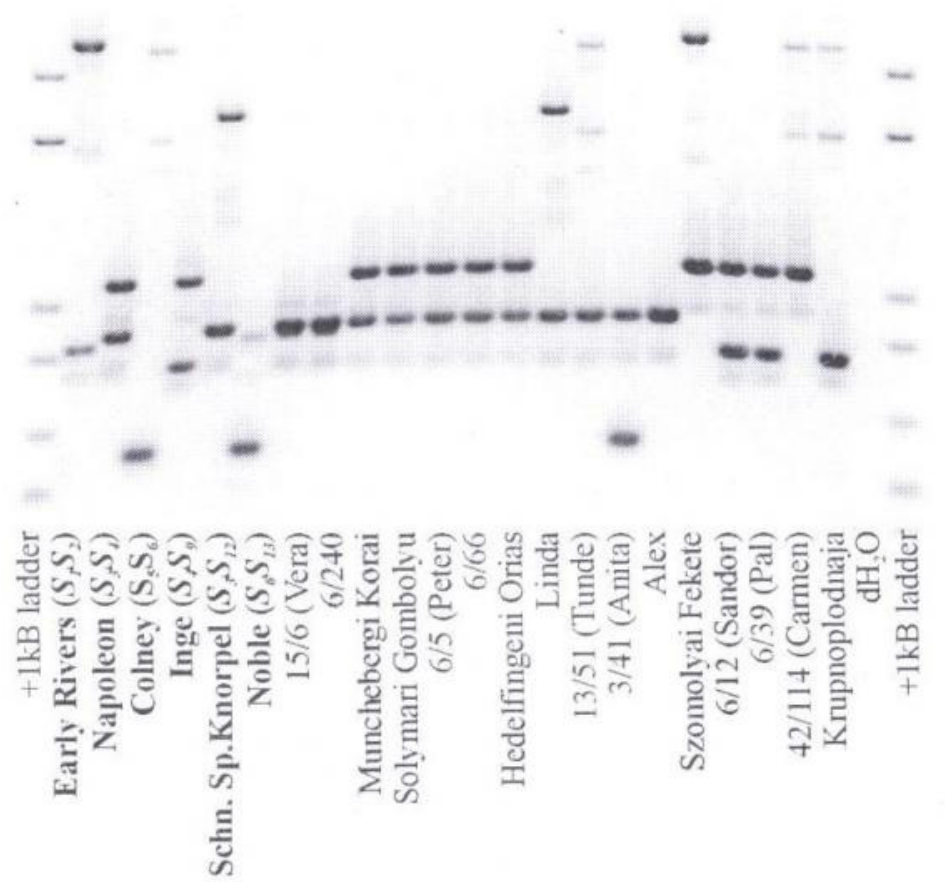

Table 2 Cherry cultivars used as standards and their $S$-genotypes

\begin{tabular}{|l|l|}
\hline \multicolumn{1}{|c|}{ Cultivar } & Genotype \\
\hline Early Rivers & $S_{1} S_{2}$ \\
\hline Victor & $S_{2} S_{3}$ \\
\hline Lapins & $S_{1} S_{4}$ \\
\hline Napoleon & $S_{3} S_{4}$ \\
\hline Late Black Bigarreau & $S_{4} S_{5}$ \\
\hline Colney & $S_{5} S_{6}$ \\
\hline Charger & $S_{1} S_{7}$ \\
\hline Inge & $S_{4} S_{9}$ \\
\hline Orleans 171 & $S_{7} S_{11}$ \\
\hline Schneiders Späte Knorpelkirsche & $S_{3} S_{12}$ \\
\hline Noble & $S_{6} S_{13}$ \\
\hline Dikkeloen & $S_{5} S_{14}$ \\
\hline
\end{tabular}

\section{Results}

Electrophoretic banding patterns of the accessions after amplification with the $2^{\text {nd }}$ intron primers are shown in Figure 1. Examining the patterns of the standard cultivars it showed that the alleles $S_{I} / S_{3} / S_{13}$ and $S_{2} / S_{5}$ are not easily distinguishable. After $1^{\text {st }}$ intron analysis (Figure 2) these alleles could be distinguished. On the basis of the $1^{\text {st }}$ and $2^{\text {nd }}$ intron analyses together it was possible to determine the $S$ genotypes of the Hungarian accessions. Finally, results were confirmed with allele-specific PCR. S-allele scores and assignment of analysed accessions into incompatibility groups are given in Table 3 .

IV-5/62 ('Rita') appears to have a new allele, $S_{x}$. Its $2^{\text {nd }}$ intron length is approximately $2300 \mathrm{bp}$ and the $1^{\text {st }}$ intron is appr. $420 \mathrm{bp}$ as estimated from its patterns. Although this

Figure I PCR amplification of the accessions with consensus primers for the 2 nd intron (cultivars in bold: standards) 

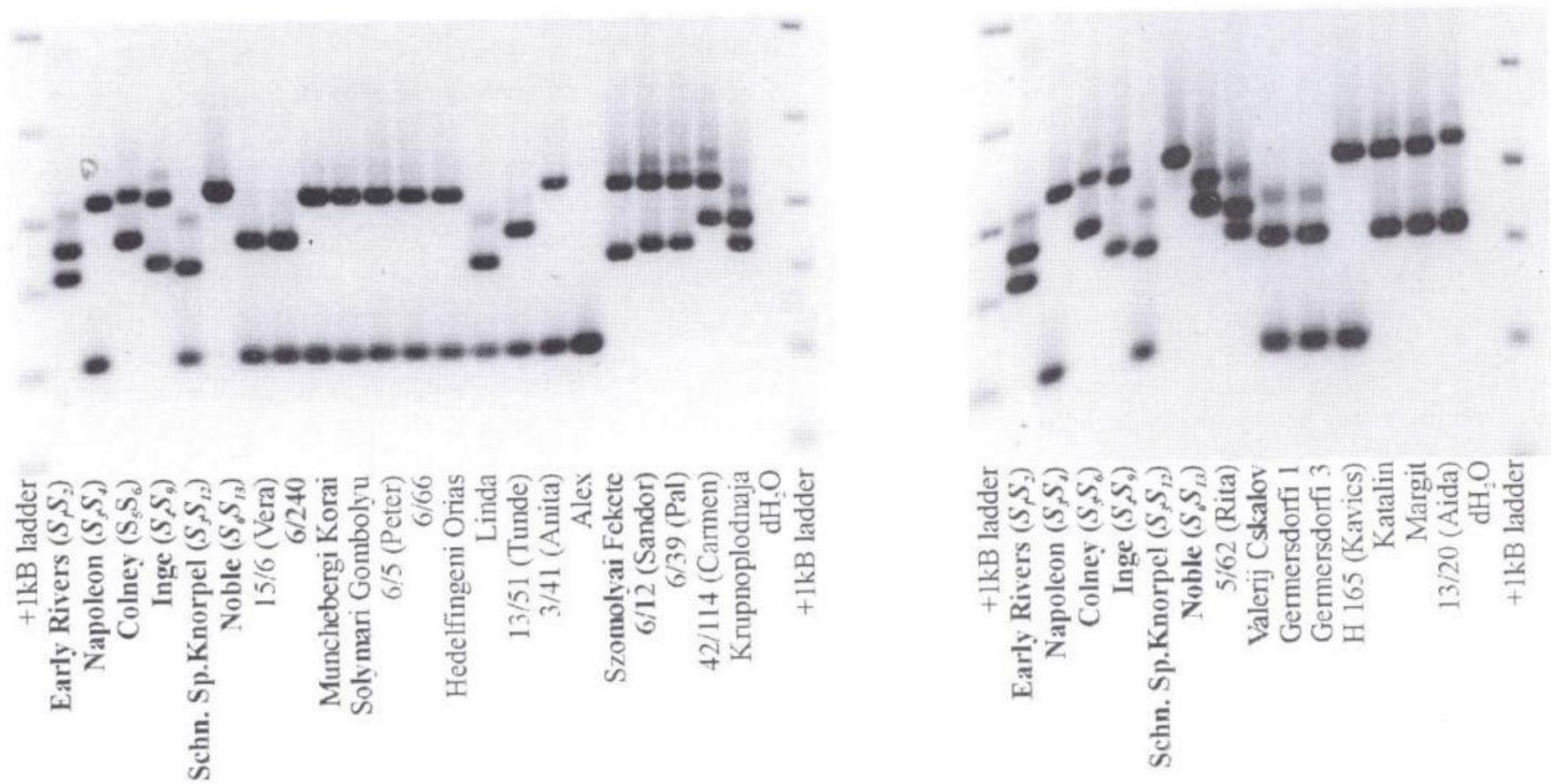

Figure 2 PCR amplification of the accessions with consensus primers for the 1st intron (cultivars in bold: standards)

intron is similar in size to $S_{2}$ and $S_{7}$ it does not amplify with primers specific for $S_{2}$ and $S_{7}$. Figure 3 shows the patterns of IV-5/62 ('Rita') after amplification with the $S_{2}$-allele specific primers. As the $S_{2}$ band is missing, but the internal control band is present, the unknown allele can not be $S_{2}$. We had similar results with $S_{7}$ allele-specific primers.

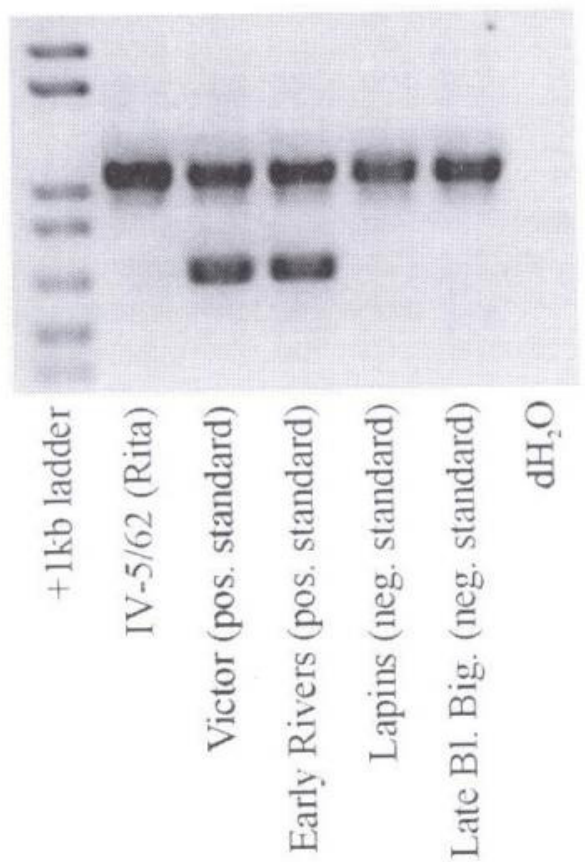

Figure 3 PCR amplification of cultivar 'Rita' with allele-specific primers for $S_{2}$
The banding patterns of 'Germersdorfi 1' and 'Germersdorfi 3' were the same. Moreover, they were the same as of 'Schneiders Späte Knorpel', thus belonging to group XXII.

The genotype of 'Valerij Cskalov', a cultivar originating from Russia, proved to be $S_{l} S_{9}$ and can be placed into group XVIII.

\section{Discussion}

Traditionally, (in)compatibility relationship of sweet cherry have been studied with test crosses in the field. However, results are greatly affected by weather, tree conditions, quality of pollen, etc. and are often inconsistent. PCR-based methods allow us to eliminate external factors and study (in)compatibility genotypes directly.

According to Table 3, of 28 accessions, 26 could be assigned to 12 of the existing incompatibility groups. The most frequent alleles were $S_{3}$ (appeared in 16 cultivars) and $S_{1}$ (in 14 cultivars) while the least common alleles were $S_{2}$. only in 'Szomolyai Fekete', a Hungarian local cultivar and $S_{x}$, in 'Rita',

'Katalin' and 'Margit' have the new genotype $S_{4} S_{12}$ thus they form a new incompatibility group (XXVII).

The genotypes of 'Krupnoplodnaja' $\left(S_{5} S_{9}\right)$ and 'Rita' $\left(S_{5} S_{x}\right)$ are unique, therefore they can be added to Group $\mathrm{O}$.

In 'Rita' we found an allele, $S_{x}$, that does not correspond to any of the known alleles $\left(S_{1}\right.$ to $S_{16}$; Sonneveld et al., 2003). Its intron sizes correspond to a new allele found in wild cherries by De Cuyper (pers. comm.) who labelled it $S_{22}$. This is the first report of the existence of $S_{22}$ allele in 
Table $3 \mathrm{~S}$-allele results of the accessions analysed

\begin{tabular}{|c|c|c|c|c|c|c|c|c|c|c|c|c|c|c|c|c|}
\hline \multirow{2}{*}{ Cultivar } & \multirow{2}{*}{$\begin{array}{l}\text { Consensus primers, } \\
\text { preliminary results } \\
\text { genotype }\end{array}$} & \multicolumn{13}{|c|}{ Allele-specific primers, confirmation } & \multicolumn{2}{|c|}{ Final results } \\
\hline & & $s_{1}$ & $S_{2}$ & $S_{3}$ & $s_{4}$ & $S_{5}$ & $S_{6}$ & $S_{7}$ & $S_{9}$ & $S_{10}$ & $S_{12}$ & $S_{13}$ & $S_{14}$ & $S_{16}$ & genotype & incomp.group \\
\hline Vera & $s_{1} s_{3}$ & + & & + & & & & & & & & & & & $s_{1} s_{3}$ & II \\
\hline IV $-6 / 240$ & $S_{1} S_{3}$ & + & & + & & & & & & & & & & & $S_{l} S_{3}$ & II \\
\hline $13 / 120$ & $S_{1} S_{3}$ & + & & + & & & & & & & & & & & $S_{t} S_{3}$ & II \\
\hline Münchebergi Korai & $S_{3} S_{4}$ & & & + & + & & & & & & & & & & $S_{3} S_{4}$ & III \\
\hline Solymári Gömbölyú & $S_{3} S_{4}$ & & & + & + & & & & & & & & & & $S_{3} S_{4}$ & III \\
\hline Hedelfingeni Orias & $S_{3} S_{4}$ & & & + & + & & & & & & & & & & $S_{3} S_{4}$ & III \\
\hline Kavics & $S_{3} S_{4}$ & & & + & + & & & & & & & & & & $S_{3} S_{4}$ & III \\
\hline Botond & $S_{3} S_{4}$ & & & + & + & & & & & & & & & & $S_{3} S_{4}$ & III \\
\hline $5 / 5$ & $S_{4} S_{5}$ & & & & + & + & & & & & & & & & $S_{4} S_{5}$ & $\mathrm{~V}$ \\
\hline III-42/114 (Carmen) & $S_{4} S_{5}$ & & & & + & + & & & & & & & & & $S_{4} S_{5}$ & $\mathrm{v}$ \\
\hline IV-3/4I (Anita) & $S_{3} S_{6}$ & & & + & & & + & & & & & & & & $S_{3} S_{6}$ & VI \\
\hline IV-13/5I (Tünde) & $S_{3} S_{5}$ & & & + & & + & & & & & & & & & $S_{3} S_{5}$ & VII \\
\hline Szomolyai Fekete & $S_{2} S_{4}$ & & + & & + & & & & & & & & & & $S_{2} S_{4}$ & XIII \\
\hline Trusenszkaja 2 & $S_{5} S_{6}$ & & & & & + & + & & & & & & & & $S_{5} S_{6}$ & $\mathrm{XV}$ \\
\hline Valerij Cskalov & $S_{l} S_{9}$ & + & & & & & & & + & & & & & & $S_{l} S_{9}$ & XVIII \\
\hline Linda & $s_{3} S_{12}$ & & & + & & & & & & & + & & & & $S_{3} S_{12}$ & XXII \\
\hline Germersdorfi 1 & $S_{3} S_{12}$ & & & + & & & & & & & + & & & & $S_{3} S_{12}$ & XXII \\
\hline Germersdorfi 3 & $S_{3} S_{12}$ & & & + & & & & & & & + & & & & $S_{3} S_{12}$ & XXII \\
\hline IV-13/20 (Aida) & $S_{6} S_{12}$ & & & & & & + & & & & + & & & & $S_{6} S_{12}$ & XXIV \\
\hline Katalin & $S_{4} S_{12}$ & & & & + & & & & & & + & & & & $S_{4} S_{12}$ & XXVII (new) \\
\hline Margit & $S_{4} S_{12}$ & & & & + & & & & & & + & & & & $S_{4} S_{12}$ & XXVII (new) \\
\hline Krupnoplodnaja & $S_{5} S_{9}$ & & & & & + & & & + & & & & & & $S_{5} S_{9}$ & 0 \\
\hline IV-5/62 (Rita) & $S_{5} S_{2} ? S_{5} S_{7} ? S_{5} S_{x} ?$ & & - & & & + & & - & & & & & & & $S_{5} S_{x}^{*}$ & $\mathrm{O}$ \\
\hline IV-6/5 (Péter) & $S_{3} S_{4}^{\prime}$ & & & + & + & & & & & & & & & & $S_{3} S_{4}$ & SC \\
\hline IV $-6 / 66$ & $S_{3} S_{4}$ & & & + & + & & & & & & & & & & $S_{3} S_{4}^{\prime}$ & $\mathrm{SC}$ \\
\hline IV-6/12 (Sándor) & $S_{4} S_{9}$ & & & & + & & & & + & & & & & & $S_{4}^{\prime} S_{9}$ & SC \\
\hline IV-6/39 (Pál) & $S_{4} S_{9}$ & & & & + & & & & + & & & & & & $S_{4} ; S_{9}$ & $\mathrm{SC}$ \\
\hline Alex & $S_{3} S_{3}^{\prime}$ & & & + & & & & & & & & & & & $S_{3} S_{3}^{\prime}$ & $\mathrm{SC}$ \\
\hline
\end{tabular}

${ }^{*} \mathrm{~S}_{x}$ is probably $S_{22}$

sweet cherry. As the female parent of 'Rita' has the genotype $S_{5} S_{6}$, this allele should come from selection ' $\mathrm{H} 2$ ', the paternal parent of 'Rita', that originates from open pollination of 'Schneiders Späte Knorpelkirsche' (Apostol, pers. comm.).

In this work it was shown that 'Germersdorfi 1' and 'Germersdorfi 3' have the same incompatibility genotype as 'Schneiders Späte Knorpelkirsche', but whether they are indeed the same cultivar, as believed among Hungarian scientists, would require fingerprinting e.g. by microsatellites. The relationship to 'Germersdorfer', an other German cultivar, could also be checked. Störtzer et al. (1992) state that 'Germersdorfer' is the synonym name for 'Schneiders Späte Knorpelkirsche'.
'Alex'shows only a single band in the $S_{3}$ position with $1^{\text {st }}$ and $2^{\text {nd }}$ intron consensus primers. From its PCR results and parentage Sonneveld et al. (2003) deduced that 'Alex', which is self-compatible, is $S_{3} S_{3}{ }^{\prime}$ '

Self-compatibility cannot be proved by these PCR methods alone as $S_{4}$ and $S_{4}^{\prime}$ give the same amplification products with the primers used. We can deduce selfcompatibility from amplification pattern if its parentage is known. Thus the $S_{4} / S_{4}$ ' band in 'Sándor', 'Pál' and in the hybrid 'IV-6/66' - which have 'Stella', $S_{3} S_{4}$ ' as a father parent, indicates the self-compatibility allele $S_{4}$ Selfcompatibility of all accessions in Group SC (Table 3) was confirmed with selfings in the field (data not shown). 
On the basis of genotyping and parentage of IV-13/51 ('Tünde') and 'IV-13/120' it was possible to determine the genotype of their maternal parent. Thus 'Yellow Dragan' must be $S_{l} S_{5}$. PCR analysis of this cultivar confirmed its proposed genotype (Schuster, pers. comm.).

According to our experiments, the cultivar grown in Hungary under the name 'Hedelfingeni Orias' was found to have the genotype $S_{3} S_{4}$ and not $S_{3} S_{5}$ as previously reported for 'Hedelfingen' grown in Western Europe. Therefore it is assumed that 'Hedelfingeni Orias' and 'Hedelfingen' are different cultivars. Again it would be useful to confirm this with microsatellite fingerprinting. To avoid mistakes we propose distinguishing this clone as 'Hedelfingen $\mathrm{O}$ '.

On the basis of our results and with knowledge of blooming times cherry growers will be able to choose the ideal cross-compatible cultivar combinations for their orchards. The breeder will also benefit, in being able to choose cross-compatible cultivar combinations for his/her crossings.

\section{Acknowledgement}

This work was supported by,the Hungarian Ministry of Education and the British Council, as a part of a HungarianBritish Intergovernmental Science and Technology Cooperation,

\section{References}

Apostol, J. \& Brózik, S. (1998): Cseresznye. In: Soltész, M. (ed) Gyümölcsfajta-ismeret és használat. Mezōgazda Kiadó, Budapest Apostolné (1994): Cseresznyefajták és -hibridek értékelése. Thesis. MTA, Budapest

Bošković, R. \& Tobutt, K.R. (1996): Correlation of stylar ribonuclease zymograms with incompatibility alleles in sweet cherry. Euphytica 90: 245-250.

Bošković, R., Russell, K. \& Tobutt, K.R. (1997): Inheritance of stylar ribonucleases in cherry progenies, and reassignment of incompatibility alleles to two incompatibility groups. Euphytica 95: 221-228.

Bošković, R., Tobutt, K.R., Sonneveld, T. \& Cerovic, R. (2000): Recent advances in cherry self-(in)compatibility studies. Acta Horticulturae 538: 351-354.

Bošković, R. \& Tobutt, K.R. (2001): Genotyping cherry cultivars assigned to incompatibility groups by analysing stylar ribonucleases. Theoretical and Applied Genetics 103: 475-485.

Brózik, S. (1962): A Germersdorfi óriás cseresznyefajta termékenyülési viszonyai. Kísérletügyi Közlemények 2: 111-144. Brózik, S. \& Nyéki, J. (1975): A cseresznye és a meggy termékenyülési viszonyai. In: Brózik, S., Nyéki, J. (eds.): Gyümölcstermố növények termékenyülése. Mezốgazdasági Kiadó, Budapest, 136-145,

Brózik, S.\& Nyéki, J. (1980): A cseresznye. In: Nyéki J. (ed.): Gyümölcsfajták virágzásbiológiája és termékenyülése. Mezốgazdasági Kiadó, Budapest, 195-204.

Brózik S.\& Apostol J. (2000): In: Brózik, S., Kállay, Tné (eds.): Csonthéjas gyümölcsfajták. Mezôgazda Kiadó, Budapest, 187.

Crane, M.B. \& Lawrence, W.J.C. (1929): Genetical and cytological aspects of incompatibility and sterility in cultivated fruits. Journal of Pomology and Horticultural Science 7: 276-301. Crane, M.B. \& Brown, A.G. (1937): Incompatibility and sterility in the sweet cherry, Prunus avium L. Journal of Pomology and Horticultural Science 15: 86-116.

Doyle, J.J. \& Doyle, J.L. (1987): A rapid DNA isolation procedure for small quantities of fresh leaf tissue. Phytochemical Bulletin 19: 11-15.

Gardener, V.R. (1914): A preliminary report on the pollination of the sweet cherry. Oregon Agricultural College Press, Corvallis, Oregon, USA. 37.

Kobel, F.P. \& Steinegger, P. (1933): Landwirtschaftlichen Jahrbuch der Schweiz 47: 973-1018.

Lewis, D. \& Crowe, L.K. (1954): Structure of the incompatibility gene. IV. Types of mutations in Prunus avium L. Heredity 8: 357-363.

Maliga, P. (1952): Badacsonyi és Germersdorfi cseresznye termékenyülési adatai. Agrár Egy. Kert. és Szổoógazdasági Kar Évkönyve 27-49.

Matthews, P. \& Dow, K.P. (1969): Incompatibility groups: sweet cherry (Prunus avium). In: Knight, R.L. (ed.): Abstract Bibliography of Fruit Breeding \& Genetics to 1965, Prunus. Commonwealth Agricultural Bureaux, Farnham Royal, 540-544.

Matthews, P. \& Lapin, K. (1967): Self-fertile sweet cherries. Fruit Varieties and Horticultural Digest 21: 36-37.

Matthews, P. (1970): Genetics and exploration of self-fertility in the sweet cherry. Proceedings of the Angers Fruit Breeding Symposium, 307-316.

Nyéki, J. (1989): Csonthéjas gyümölcsủek virágzása és termékenyülése. Thesis. MTA, Budapest.

Nyéki, J. \& Szabó, Z. (1995): Cross-incompatibility in stone fruits. Horticultural Science 28: 23-31.

Sonneveld, T., Robbins, T.P., Bošković, R. \& Tobutt, K.R. (2001): Cloning of six cherry self-incompatibility alleles and development of allele-specific PCR detection. Theoretical and Applied Genetics 102: 1046-1055.

Sonneveld, T., Tobutt, K.R. \& Robbins, T.P. (2003): Allelespecific PCR detection of sweet cherry incompatibility $(S)$ alleles $S_{1}$ to $S_{16}$ using consensus and allele-specific primers. Theoretical and Applied Genetics 107: 1059-1070.

Störtzer, M., Wolfram, B., Schuricht, W. \& Männel, R. (1992): Steinobst. Neumann, 148.

Szabó, Z., Nyéki, J. \& Soltész, M. (2002): Cseresznye. In: Nyéki, J., Soltész, M. \& Szabó, Z. (eds.): Fajtatársítás a gyümölcsültetvényekben. Mezógazda Kiadó, Budapest, 177-192.

Tao, R., Yamane, H., Sugiura, A., Murayama, H., Sassa, H. \& Mori, H. (1999): Molecular typing of S-alleles through identification, characterisation and cDNA cloning for S-RNases in sweet cherry. Journal of the American Society for Horticultural Science 124: 224-233.

Tobutt, K.R., Sonneveld, T. \& Bošković, R. (2001): Cherry (in)compatibility genotypes - harmonization of recent results from UK, Canada, Germany, Japan and USA. Eucarpia Fruit Breeding Section Newsletter Nr. 5, 41-46.

Tobutt, K.R., Sonneveld, T., Bekefi, Z. \& Bošković, R. (in press): Cherry (in)compatibility genotypes - an updated cultivar table.

Wiersma, P.A., Wu, Z., Zhou, L., Hampson, C. \& Kappel, F. (2001): Identification of new self-incompatibility alleles in sweet cherry (Prunus avium L.) and clarification of incompatibility groups by PCR and sequencing analysis. Theoretical and Applied Genetics 102: 700-708. 